\title{
DEVELOPMENTS AND REFORMS IN SMALL BUSINESS SUPPORT INSTITUTIONS SINCE 1996
}

\author{
S Molapo, Ministry of Finance and Development Planning, Lesotho and RR Mears \& JMM Viljoen, \\ University of Johannesburg, South Africa
}

Purpose/objectives: The aim of the paper is to investigate the successes and shortcomings of the support services provided by the different Small Business Support institutions during the period 1996 to 2003. It also evaluates the recent developments in these Small Business Support institutions.

Problem investigated: Many small businesses are still excluded from funds and support from Small Business Support Institutions. The paper investigates the extent to which these institutions provided financial as well as non-financial support to SMMEs in South Africa during the period 1996 to 2003. The paper further explores the changes in the legislation in 2004 in this regard, and explains how it intends to extent support to SMMEs.

Design/Methodology/Approach: The paper assesses the small business development policy framework in terms of the functions and assistance of the Small Business Support institutions. Secondly, it analyses the microeconomic evaluation of the services provided for the period 1996 to 2003. This is followed by a macroeconomic evaluation of the impact of support programmes on employment creation, poverty alleviation and economic empowerment. Lastly, the successes and shortcomings of these support programmes are identified and changes since 2003 discussed.

Findings/Implications: The fact that many SMMEs still do not get support, points to the shortcomings in the support programmes. Most programmes do not cater for the very small and micro-enterprises and most benefits from these programmes benefit SMMEs in urban areas.

Originality/Value: The paper finds an original way to explain the shortcomings of Small Business Support institutions and the lack of data from these institutions since 2003. These institutions must do more than banks and also help those that can not be accommodated by commercial banks.

Conclusion: The Small Business Support institutions must help the very small and micro-enterprises that can not be accommodated elsewhere.

Key words and phrases: SMMEs (Small, medium and micro-enterprises), Micro-financing, Ntsika, Small Business Development Agency (SEDA), Apex fund, Khula

\section{INTRODUCTION}

South Africa developed a Small Business Development Policy in 1996 in order to create an enabling environment for the growth and development of small businesses. The policy aims to enhance the capacity of small businesses to comply with the demands of the modern economy and the challenges brought about by globalisation and increasing international competition. Capacity-building can enable small businesses to improve the quality of their products and services, to improve their ability to compete effectively internationally and to empower them to access funds from the formal banking sector (DTI, 1996a:15). The policy is a consequence of the shrinking job opportunities in the big business sector which forced the government to focus on small businesses in the formal and informal sectors for employment creation (Nigrini \& Schoombee, 2002:735). Small businesses are now considered a mechanism for creating employment, reducing poverty and addressing other socio-economic imbalances.

A number of institutions were established to provide financial as well as non-financial support to small businesses in South Africa. The government also introduced government assistance programmes to help enhance the capacity of small businesses. Not all of these programmes were however successful. The 
inability of some of these institutions to deliver the results expected, made changes in the framework of providing support to small businesses inevitable.

\section{AIM AND OBJECTIVES}

The aim of the research is to investigate the successes and shortcomings of the support services provided by the different Small Business Support (SBS) institutions during the period 1996 and 2003, and to evaluate the recent developments in these SBS institutions. In order to achieve this aim, the objectives are firstly, to assess the small business development policy framework in South Africa in terms of the functions of the SBS institutions and ways in which they assist small businesses. Secondly, it analyses the microeconomic evaluation of the services provided by the SBS institutions for the period 1996 and 2003. This analysis is based on a literature study and includes issues such as the awareness and attempted usage of small businesses regarding assistance programmes offered by institutions such as Ntsika, Khula and the DTI, the proportion of assistance rendered to those who sought assistance, the cost of assistance and funding received and the quality of assistance by these institutions.

The microeconomic analysis is followed by a macroeconomic evaluation of the impact of the support programmes on employment creation, poverty alleviation and economic empowerment. Lastly, the paper identifies the successes and shortcomings of these support programmes during the period 1996 and 2003 and discusses some of the changes in the small business support framework after 2003.

The significance of this research is to broaden the knowledge and understanding of the various support programmes available to small businesses as well as to highlight the lessons learnt from the past in terms of the accessibility and perceptions amongst small businesses regarding the quality of these support programmes. The paper will conclude with a summary of the main findings.

\section{SMALL BUSINESS SUPPORT INSTITUTIONS IN SOUTH AFRICA}

After South Africa's first democratic election in 1994, a number of institutions were established to provide support to small businesses in South Africa. These institutions include the Ntsika Enterprise Promotion Agency (now incorporated into the Small Business Development Agency (SEDA), Khula Enterprise Finance Ltd, DTI institutions and the Provincial Desks. Each of these institutions has its own mandate and services, either financial or non-financial services. The following sub-sections discuss each of the abovementioned institution's main services to Small, Medium and Micro Enterprises (SMMEs).

\section{Ntsika}

According to the DTI (1996b:3), Berry, Von Blottnitz, Cassim, Kesper, Rajaratnam and Van Seventer (2002:36), and the World Bank (2005:80), Ntsika was established to implement the national small business development strategy. Ntsika provides non-financial support and business development to small businesses through a number of programmes, such as the Local Business Service Centres (LBSCs), mentorship programmes for SMMEs, Tender Advice Centres (TACs) and the Trade and Industrial Development Programme. According to the Government Information System (GIS, 2006:18), the LBSCs provide business counseling and advice, training, information and networking. The TACs provide assistance in the form of training on government procurement processes and also on current tenders (Berry et al., 2002:36 and World Bank, 2005:80). Other services provided by Ntsika include the facilitating and coordinating of access to technology and the enhancing of the skills of small business trainers.

\section{Khula Enterprise Finance}

Khula Enterprise Finance Ltd was established in 1996 to provide loan guarantees to small businesses in order to increase their access to finance through commercial banks. Khula Enterprise Finance Ltd has established a number of loan schemes to increase access to finance for small businesses through banks, Retail Finance Intermediaries (RFIs) and Micro-credit Organisations (MCOs). They undertake the 
selection process of loan applications from small businesses. They further require business plans from all applicants in order to determine the viability of their projects. The current programmes under this scheme are credit guarantee schemes, the business loan scheme, seed loans, the equity fund and the Khula Start (Berry et al., 2002:37; DTI, 1996b:3; and World Bank, 2005:80).

The Standard Credit Guarantee Schemes (SCGs) for small businesses are aimed at providing increased access to finance through commercial banks. The scheme allows the entrepreneur to access funding for the establishment, expansion or acquisition of a new or existing business. The SCGs provides indemnity to the bank for a maximum amount of R600 000. RFIs who wish to access finance from their bankers to fund their lending operations to small businesses may be assisted through this scheme. Guarantees to an RFI may be extended where the portfolio of the small business is beyond its prudent lending practice. For some targeted sectors, Khula may indemnify the RFI up to 80 percent of the irrecoverable loss. The scheme is accessible to small businesses that are independently owned and with assets less than R20 million. In this case, Khula sets the criteria for the guarantees (Eksteen, 2001:49).

The Business Loan Scheme provides business loans to RFIs for funding or lending to small businesses which meet the requirements. The loan amounts for less experienced RFIs range from R1 million to R10 million and for experienced RFIs, it ranges between R5 million and R100 million. Less experienced RFIs have to provide credible plans for operations, management, credit policy guidelines and operating procedures. This should also indicate an operational stability within the next 5 years. More experienced RFIs must be able to self-fund their programmes for at least the first 2 months of implementation. They must also indicate and explain an operational stability within 3 years and financial stability within 5 years (Eksteen, 2001:51; DTI, 2008:1).

Seed Loans for RFIs provides initial capital to new organisations entering the RFI market. They need start-up capital to initiate their portfolio and fund operational expenses over a given period. These seed loans can be converted into grants under certain conditions. Seed loans range from R50 000 to R20 million for under-capitalised RFls which are legally constituted, have a clearly defined small business target market and have sound accounting and financial systems. Other criteria include sound internal organisational guidelines, policies and procedures. They must have sufficient internal capacity to undertake the proposed projects, have clear short and long-term objectives, and have 15 percent of their own capital (Eksteen, 2001:52).

The Equity Fund is ear-marked for companies which require equity partners to assist them in their expansion and development plans. The fund finances joint ventures, expansions, re-capitalisation of companies and the buying-in and buying-out of existing shareholders for small business that need to expand their operations (Eksteen, 2001:54). The Fund contributes up to 49 percent of the equity funds and will disinvest when the business becomes profitable within 2 to 7 years. Small businesses with a net asset value of less than R500 000, which are viable in the medium and long-term and which expect an adequate rate of return, are eligible to access the Equity Fund (DTI, 2008:2).

Khula Start funding promotes greater access to micro-credit in rural areas. This is a group lending scheme for the lower end of the micro-enterprise market. The target group is the historically disadvantaged communities especially women in rural areas and the informal sector. The scheme provides loans of between R300 and R3500 and is accessible to existing Non-Governmental Organisations (NGOs). It is based in rural areas and is involved in small business activities such as business training and advice (Eksteen, 2001:55).

To increase access to finance through banks, for establishing or acquiring of a new or existing business, the Emerging Entrepreneur Scheme and the Empowerment Scheme was established. The Emerging Entrepreneur Scheme is accessible to SMMEs with assets less than R2 million. The maximum amount of the loan is R70 000 (DTI, 2008:2). The Empowerment Scheme is accessible for bank loans to SMMEs who lack collateral. The maximum loan is R5 million. The loan only covers 60 percent of the loan application and the maximum term is 5 years (DTI, 2008:1) 
Nigrini and Schoombee (2002:740) outline the criteria for qualification under the Khula programmes. These criteria have also been accepted by commercial banks that participate in these programmes. Firstly, the owner should have at least a 10 percent contribution of own resources in the form of assets or cash to qualify. In some cases, commercial banks require 20 percent depending on the evaluation of the individual's risk. The agreement also requires that the borrower be a hands-on owner or manager of the business on a full-time basis. Moreover, the borrower should be the majority shareholder and a South African citizen. The borrower needs to be in possession of the required skills and training, relevant to the industry within which the business will be operating. Secondly, the business should be registered in South Africa and should have other support systems such as financial and accounting systems as well as business plans. It should further be established with a profit motive and the business should be sustainable. The sustainability is measured in terms of the applicant's ability to manage the business and the loan, to reduce the risk to the bank. Finally, the business should not be operating in the agricultural sector or commercial building sector. This shows that even the government subsidised financing must comply with stringent requirements to qualify for subsidies.

\section{Department of Trade and Industry (DTI) institutions}

The DTI provides a number of incentive schemes for registered small businesses. The Standard Leased Factory Building Scheme (SLFBS) is administered by the Industrial Development Corporation (IDC). The scheme assists small manufacturers to acquire factory buildings for leasing (Berry et al., 2002:37-38; Rogerson, 2004:768 and Orford \& Wood, 2005:6).

The Small and Medium Manufacturing Development Programme (SMEDP) consists of a tax-exempt establishment grant and the Skills Support Programmes (SSP) for small businesses (Berry et al., 2002:37-38 and Rogerson, 2004:768). According to Orford and Wood (2005:6) and the GIS (2006:14) this is a tax holiday programme for smaller projects. This encourages employment creation, strengthening existing businesses and encouraging small businesses to expand.

Berry et al., (2002:37-38) and Rogerson (2004:768), state that Economic Empowerment Schemes (EESs) are mainly established for the expansion or establishment of small businesses from the previously disadvantaged individuals. The IDC contributes the majority of the capital outlay for the EESs (Orford \& Wood, 2005:6).

The Venture Capital Scheme (VCS) is for viable projects or ventures and is co-financed by the Industrial Development Corporation (IDC). Venture capital is a form of private equity that focuses on relatively highrisk businesses, while expecting a return on investment of at least 35 percent per annum. The small businesses do not have sufficient growth potential to attract venture funders due to their internal lack of capacity (SEDA, 2006:3).

The Normal Finance Scheme (NFS) provides for low-interest IDC administered funds during the expansion phase of the project. The businesses must have demonstrated sufficient potential for growth (Berry et al., 2002:37-38; Rogerson, 2004:768 and Orford \& Wood, 2005:6).

The Import Finance Scheme (IFS) is administered by the DTI and it consists of credit guarantee facilities for local industrialists to import capital goods. By 1999, R400 million had already been provided to local industrialists under this scheme (Eksteen, 2001:23).

The Short-term Export Finance Guarantee Facility (STEFGF) provides an arrangement with the Credit Guarantee Insurance Corporation (CGIC) for post and pre-shipment export finance guarantees for small businesses (Berry et al., 2002:38). According to Eksteen (2001:43), the scheme aims to reduce the exporter's risk normally borne by commercial banks, especially where exporters are small businesses. The scheme is accessible to small businesses involved in the export of goods in all sectors. 
The Export Marketing and Investment Assistance Scheme (EMIA) aims to assist exporters with costs incurred for activities to develop export markets for South African products and bringing foreign direct investment to South Africa. The scheme is divided into 8 main areas of assistance namely, primary export market research, FDI research, exhibition assistance, outward-selling trade missions, outward investment recruitment missions, inward-buying trade missions, inward investment missions, and membership with an export council. The scheme further provides for Export Credit and Foreign Investment Re-insurance (ECFIR) under short, medium and long-term insurance. It also includes export finance for capital goods and projects, foreign investment guarantees, and export finance guarantees for small businesses. The scheme is accessible to South African companies meeting these objectives (Eksteen, 2001:45).

\section{Provincial SMME Desks}

The Provincial SMME desks have been established to represent the interests of small business and to contribute to the implementation of the national small business strategy. These institutions also coordinate national or sectoral programmes with local or regional implementation bodies and have established a comprehensive small business database. This forms the basis for national policy.

\section{The Manufacturing Advice Centres}

The Manufacturing Advice Centres (MACs) are coordinated and monitored by the National Manufacturing Advice Centre (NAMAC) and the Centre for Scientific and Industrial Research (CSIR). Both NAMAC and the CSIR provide industry specific assessment and are a link between small businesses and the highly specialised service providers (Berry et al., 2002:36 and World Bank, 2005:80). According to Swiss-South Africa Cooperation on Investment (SSACI) (2002:5), the scheme aims to support micro and very small businesses in the manufacturing sector. This is done through advice in areas such as accessing finance, developing quality assurance systems, improving productivity, managing human resources and marketing. The next section evaluates the programmes of these institutions for the period 1996 to 2003.

\section{EVALUATION OF SMALL BUSINESS SUPPORT PROGRAMMES FOR THE PERIOD 1996 TO 2003}

The small business support programmes are evaluated in terms of their microeconomic impact and thereafter on their macroeconomic impact for the period 1996 to 2003.

\section{Microeconomic Evaluation of SMME Support Programmes}

Chandra et al., provide an evaluation of the small business support programmes in South Africa in a survey in 1999 in which 792 small businesses in the Greater Johannesburg area participated (Berry et al., 2002:42). They evaluate these programmes against five criteria. The first criterion of evaluation is the awareness by small entrepreneurs of small business support institutions and programmes and whether they have approached these institutions for support. It further evaluates whether small businesses, who approached the institutions, received assistance, and what the cost and quality of assistance are. The results of the survey are presented in Table 1. 
Table 1: Comparison of the use of Ntsika, Khula and DTI programmes in Greater Johannesburg1999.

\begin{tabular}{|l|c|c|c|c|c|}
\hline & $\begin{array}{c}\text { Small } \\
\text { Business } \\
\text { awareness of } \\
\text { the } \\
\text { programmes } \\
(\%)\end{array}$ & $\begin{array}{c}\text { Requested } \\
\text { assistance } \\
(\%)\end{array}$ & $\begin{array}{c}\text { Assistance } \\
\text { Received } \\
(\%)\end{array}$ & $\begin{array}{c}\text { Quality of } \\
\text { assistance } \\
(\%)\end{array}$ & $\begin{array}{c}\text { Fair cost of } \\
\text { assistance/ } \\
\text { funding } \\
\text { received } \\
(\%)\end{array}$ \\
\hline $\begin{array}{l}\text { Ntsika/Khula } \\
\text { Programmes }\end{array}$ & 36 & 19 & 67 & 77 & 85 \\
\hline $\begin{array}{l}\text { DTI } \\
\text { Programmes }\end{array}$ & 67 & 15 & 88 & 95 & 46 \\
\hline
\end{tabular}

Source: Chandra et al. in Berry et al., (2002:42).

The data in Table 1 also give a comparison between the results of the programmes of Ntsika, Khula and DTI. The awareness of the existence of support programmes to SMMEs is calculated as a percentage of the total number of respondents, while both the quality of assistance and the cost of funding are calculated as a percentage of those who received assistance under these programmes.

Table 1 shows that 67 percent of the 792 respondents in Gauteng are aware of the existence of the DTI programmes. Only 36 percent of the 792 respondents are aware of Ntsika and Khula programmes. Only 15 percent of those 67 percent, who are aware of the DTI programmes have actually sought assistance from them compared to 19 percent of the 36 percent who were aware of programmes from Ntsika and Khula. Of all those who sought assistance from DTI, 88 percent were assisted compared to 67 percent by Ntsika and Khula. Respondents generally show satisfaction with the quality of assistance offered by Ntsika, Khula and DTI programmes. This has been confirmed by 95 and 77 percent of the respondents who received assistance, for DTI and Ntsika or Khula programmes respectively. Finally, 85 percent of the respondents are of the opinion that Ntsika or Khula's cost of assistance is fair compared to only 46 percent for DTI.

\section{Macroeconomic Evaluation of SMME Support Programmes}

Rogerson (2004:765-784) evaluates the performance of the government's small business programmes for the period 1994 and 2003 on three macroeconomic criteria, namely, employment creation by small businesses, poverty alleviation and economic empowerment. Regarding employment creation, the contribution of small businesses is low. Small businesses often do not expand beyond one person operations throughout their lifetime. This hampers their expected contribution to employment creation. Although micro-enterprises form a large portion of small businesses in South Africa, this category has little prospects for further growth and development in terms of employment creation and annual turnover (Rogerson, 2004:770; Qualmann, 2000:41).

According to Kesper (2002:164) and Rogerson (2004:771), small businesses that are growing in terms of the profit performance index are also faced with the phenomenon of jobless growth, just like their large counterparts. Small business development will not necessarily translate into employment creation, especially for the unskilled labour force, as small businesses have a low propensity to create jobs. This was confirmed by the study undertaken in Gauteng as mentioned in the preceding paragraph. Therefore, small businesses may not necessarily be vehicles through which the government can create employment in the economy.

The second criterion for evaluating the performance of government programmes in small business development is their impact on poverty alleviation. The fact that participants in most cases are women, the disabled and rural households have contributed to poverty alleviation, as these are the most vulnerable groups in the society. 
The third criterion for evaluating the impact of the government's programmes in small business development is on economic empowerment. Manning (1996:65) and Rogerson (2004:772) argue that small business development cannot be the only vehicle that policy-makers use to address the problem of high income inequality in the economy. They state that the government programmes have been able to facilitate the empowerment of the previously disadvantaged communities. Although these government programmes facilitated the empowerment of the previously disadvantaged individuals, they also created an unequal share of the benefits derived from such empowerment.

According to Rogerson (2004:772), the SMEDP has only been able to allocate 4,6 percent of their funding to small businesses from the previously disadvantaged individuals. About 95 percent of the programme's funding has been utilised by small businesses with white ownership. Qualmann (2000:1) and Dorfling (2001:108) argue that Ntsika and Khula have performed their mandate more successfully. However, more needs to be done to scale up their support programmes.

According to Bredenkamp (2002:39) and Nigrini and Schoombee (2002:741), Khula Enterprise Ltd has made a positive impact on the South African economy since its inception in 1996. Between 1996 and 2002 Khula has supported small businesses under its assistance programmes. These programmes have created 787000 job opportunities. During the same period, 89000 small and very small enterprises were assisted under Khula loans through non-bank intermediaries to the value of R230 million. In the same period, Khula also approved 1500 credit guarantee schemes worth R350 million. In the rural areas and informal settlements, Khula assisted 12000 informal traders with micro loans to the value of R11 million. Moreover, about 700 aspiring entrepreneurs benefited from the Thuso Mentorship programme under Khula (Khula, 2002:2). It is impossible to determine how many of these employment opportunities were lost due to the subsequent failure of some of these businesses.

In 1999, Khula received 3157 applications and of these applications only 7 percent were rejected as they did not meet all the requirements for assistance. In 2002, the picture became much better and from 2144 applications received by Khula, only 0,7 percent were rejected. Khula has put in place proper investigative mechanisms and proper loan approval criteria. This shows that small businesses are becoming more competent in meeting the stringent financing criteria of government institutions (Nigrini \& Schoombee, 2002:741). There are, however, no data or records available to determine the performance of these loans in terms of their repayment rate.

The owner of the business is expected to contribute at least 10 percent of its own resources in the form of assets to qualify. In most cases, commercial banks require 20 percent depending on the individual's risk. The 20 percent guarantee requirement from the banks is below the international standard of 30 percent. Under normal circumstances, commercial banks in South Africa would be more willing to participate in the scheme. Khula is allowed by law to pass all the risk to the bank if the borrower defaults and if it feels the bank withheld some important information or should have taken extraordinary measures to control the risk. Therefore, commercial banks are less willing to participate in the scheme. Most commercial banks feel that the process puts them in a disadvantaged position if they have to incur the burden of the risk of default by small businesses. This is a major hindrance to commercial banks' participation. The government has to review the regulations in order to make them more transparent and more acceptable to commercial banks. This will allow commercial banks to participate without reservations (Nigrini \& Schoombee, 2002:749). Moreover, if the selection is not done properly, many of these loans become grants as they are not paid back.

In 2001, the Bureau of Market Research (BMR) of the University of South Africa (UNISA) evaluated the Khula programmes based on a number of criteria (Makina \& Malobola, 2004:805). This included job creation, gender empowerment, rural versus urban breakdown of beneficiaries, income and wealth effects, household support, and financing of new versus existing businesses. The results of the study from 1996 to 2001 are presented in Tables 2 to 4 . 
Table 2: Employment creation through Khula Enterprise Finance assistance programmes - 1996 to 2001 *

\begin{tabular}{|l|c|c|c|c|c|}
\hline $\begin{array}{c}\text { Estimated } \\
\text { Total } \\
\text { Employment }\end{array}$ & MCO & RFIs & $\begin{array}{c}\text { Individual } \\
\text { Credit } \\
\text { Guarantee } \\
\text { Scheme }\end{array}$ & $\begin{array}{c}\text { Portfolio Credit } \\
\text { Guarantee } \\
\text { Scheme }\end{array}$ & Total \\
\hline Male & 4038 & 437835 & 11601 & 1486 & 454960 \\
\hline Female & 18763 & 307378 & 5453 & 1143 & 332737 \\
\hline Total & 22801 & 745213 & 17054 & 2629 & 787697 \\
\hline Full-time & 21968 & 642455 & 15166 & 2271 & 681860 \\
\hline Part-time & 833 & 102758 & 1888 & 358 & 105837 \\
\hline Total & 22801 & 745213 & 17054 & 2629 & 787697 \\
\hline
\end{tabular}

Source: Makina and Malobola (2005:4).

* Comparable data is not available for the period after this study.

Table 2 shows the employment created through Khula Enterprise Finance assistance programmes between 1996 and 2001. It shows that these programmes have a significant impact on employment creation. RFIs have created more jobs than other assistance programmes. They have created 437832 and 307378 jobs for males and females respectively. They have also created 642455 sustainable full time jobs, which are higher than other programmes. In the period under review, Khula was able to create 787837 jobs, therefore its impact has been positive towards job creation (Makina \& Malobola, 2005:4).

Table 3 discusses the rural and urban breakdown of household support programmes by Khula Enterprise Finance Ltd.

Table 3: Rural versus urban breakdown and household support - 1996 to 2001

\begin{tabular}{|c|c|c|c|c|c|c|}
\hline Item & $\begin{array}{l}\text { Micro Credit } \\
\text { Outlets } \\
\text { (MCOs) }\end{array}$ & $\begin{array}{c}\text { Retail } \\
\text { Finance } \\
\text { Institutions } \\
\text { (RFIs) } \\
\end{array}$ & $\begin{array}{c}\text { Individuals } \\
\text { Credit } \\
\text { Guarantee } \\
\text { Scheme }\end{array}$ & $\begin{array}{l}\text { Portfolio } \\
\text { Credit } \\
\text { Guarantee } \\
\text { Scheme }\end{array}$ & $\begin{array}{c}\text { Thuso } \\
\text { Mentorship } \\
\text { Scheme }\end{array}$ & $\begin{array}{l}\text { Regional } \\
\text { Equity } \\
\text { Funds }\end{array}$ \\
\hline \multicolumn{7}{|c|}{ Spatial Composition (\%) } \\
\hline Urban & 30,0 & 60,4 & 86,6 & 42,9 & 76,8 & 93,3 \\
\hline Rural & 70,0 & 39,6 & 13,4 & 57,2 & 23,2 & 6,7 \\
\hline \multicolumn{7}{|c|}{ Dependency on Khula supported business } \\
\hline \multicolumn{7}{|c|}{$\begin{array}{l}\text { Percentage of owners deriving more than } 50 \% \text { of household income from business (excluding don't } \\
\text { know/cannot say). }\end{array}$} \\
\hline$\%$ & 26,6 & 32,8 & 39,5 & 15,1 & - & - \\
\hline \multicolumn{7}{|c|}{ Estimated number of people financially dependent on: } \\
\hline Business & 73981 & 1417154 & 25489 & 6888 & - & - \\
\hline
\end{tabular}

Source: Makina and Malobola (2005:4).

Table 2 shows that 70 percent of the micro-credit outlets were available in the rural areas against 30 percent in the urban areas. The Retail Finance Institutions (RFIs) are available to 60,4 percent of the urban households compared to 39,6 percent of the rural household. Individual Credit Guarantee Schemes have assisted 86,6 percent of the urban households and only 13,4 percent of the rural population. This confirms that more has to be done in rural areas and for very small and micro-enterprises. 
Table 4: Loan features - 1996 to 2001

\begin{tabular}{|l|c|c|c|c|c|c|}
\hline \multicolumn{1}{|c|}{$\begin{array}{c}\text { Item } \\
(\%)\end{array}$} & $\begin{array}{c}\text { MCOs } \\
(\%)\end{array}$ & $\begin{array}{c}\text { RFIs } \\
(\%)\end{array}$ & $\begin{array}{c}\text { Individual } \\
\text { Credit } \\
\text { Guarantee } \\
\text { Scheme } \\
(\%)\end{array}$ & $\begin{array}{c}\text { Portfolio } \\
\text { Credit } \\
\text { Guarantee } \\
\text { Scheme } \\
(\%)\end{array}$ & $\begin{array}{c}\text { Thuso } \\
\text { Mentorship } \\
\text { Scheme } \\
(\%)\end{array}$ & $\begin{array}{c}\text { Regional } \\
\text { Equity } \\
\text { Funds or } \\
\text { REF } \\
(\%)\end{array}$ \\
\hline $\begin{array}{l}\text { Beneficiaries } \\
\text { with only } \\
\text { Khula } \\
\text { supported } \\
\text { loan }\end{array}$ & 97,7 & 95,1 & 95,3 & 96,4 & - & - \\
\hline $\begin{array}{l}\text { Application } \\
\text { of loan }\end{array}$ & 30,2 & 52,6 & 67,0 & 26,8 & - & 56,7 \\
\hline $\begin{array}{l}\text { Start-up of } \\
\text { business }\end{array}$ & 69,1 & 41,8 & 23,7 & 17,9 & - & 36,7 \\
\hline $\begin{array}{l}\text { Consolidate } \\
\text { credit }\end{array}$ & 0,9 & 2,2 & 2,2 & 0,0 & - & 0,0 \\
\hline $\begin{array}{l}\text { Continuation } \\
\text { of business }\end{array}$ & 0,0 & 5,4 & 5,4 & 32,1 & - & 0,0 \\
\hline Other & 0,2 & 3,6 & 3,6 & 25,0 & - & 6,6 \\
\hline
\end{tabular}

\section{Source: Makina and Malobola (2005:4).}

The Portfolio Credit Guarantee Scheme, Thuso Mentorship Scheme and Regional Equity Funds (REFs) have assisted $42,9,76,8$ and 93,3 percent of the urban households respectively, compared to $57,2,23,2$ and 6,7 percent of the rural households respectively. The Micro Credit Organisations (MCOs) and PCGs are the only programmes available to more than 50 percent of the rural households. The rest of the programmes are more inclined towards assisting the urban populations (Makina \& Malobola, 2005:6).

According to Makina and Malobola (2005:6), the results further show that the concentration of employment and other benefits are better in urban areas, especially for RFls. The rural population receives less than a quarter of the Thuso Mentorship Scheme benefits. This is mainly due to a lack of infrastructure in the rural areas.

\section{Shortcomings of SMME Support Programmes during the Period 1996 to 2003}

A number of shortcomings have been identified from the micro and macroeconomic evaluation of small business support programmes during the period 1996 and 2003. There has been a perception by small businesses as well as by government that financial and non-financial institutions and agencies were not meeting the needs of the small business sector. Many small firms are still excluded from funds and support for reasons that ranges from not being aware of the existence of the small business support programmes, to the fact that these programmes are not easily accessible for a number of reasons. One of the reasons is the concern that the criteria to access funding support are too strict. Another reason is that the cost of the funding is too high. Support to small and micro-enterprises is therefore still very limited.

According to Wadula (2003:1), government admitted that its financial and non-financial institutions and agencies were not meeting the needs of developing and sustaining the growth of the small business sector. Ntsika has also been negatively perceived by the public. In a study by Chalera $(2006,279)$, the general view was that Ntsika has become a wasteful bureaucracy and out of touch with the SMMEs. Some of Ntsika's programmes are however a success such as the TACs and its technology programmes.

Some programmes are also not effective in their operations and management. Some institutions find it difficult to carry out their mandates as they have to rely on commercial banks' and RIFs participation in 
these programmes. Some institutions are perceived as scattered, unfocussed and inefficiently managed (Chalera, 2006:279). The concentration of employment and other benefits from these programmes are also better in urban areas. In general, most institutions mainly help those who can help themselves and will also be accommodated by commercial banks. The very small and micro-enterprises find it very difficult to obtain assistance for the SMME support programmes. The next section analyses the reforms and developments since 2003 to address these shortcomings.

\section{REFORM AND DEVELOPMENTS IN SMALL BUSINESS SUPPORT INSTITUTIONS SINCE 2003}

The National Small Business Act of 1996 was amended in 2004 following concerns from the government that the existing small business legislation had a minimal impact on developing the SMME sector (Wadula, 2003:1). The government's Integrated Small Enterprise Development Strategy explains the way forward for small enterprise development in South Africa for the next ten year period from 2005 to 2014 . The strategy is based on three pillars. Firsly, it aims to promote entrepreneurship through campaigns, leadership training and awards. Secondly, it aims to strengthen the enabling environment through more flexible regulations, better access to finance and markets, improved infrastructure facilities and business support. Lastly, it enhances competitiveness and capacity at the enterprise level through skills training, more focused quality-, productivity- and competitiveness-support and the facilitation of technology transfer and commercialisation of incubation (DTI, 2005:4).

Reform in the small business framework affected most of the SMME support institutions. The main institutional reforms set out in the integrated small enterprise development strategy include the recent establishment of the Small Enterprise Development Agency (SEDA), which is to localise support to SMMEs through a national network of access points, the establishment of the South African MicroFinance Apex Fund (SAMAF) and a more focused approach by Khula to service small to medium-sized enterprises. The objectives and the services offered by these SMME support institutions will now be discussed briefly.

\section{Small Enterprise Development Agency (SEDA)}

In 2003, all provisions pertaining to Ntsika Enterprise Promotion Agency were cancelled, and the DTI's enterprise organisation institutional framework was aligned to enhance its assistance to small business. This provided for the establishment of the Small Enterprise Development Agency (SEDA). SEDA makes provision for the incorporation of the Ntsika Enterprise Promotion Agency and the National Manufacturing Advisory Centre and any other designated institutions (DTI, 2004:1). This step was taken to address Ntsika's negative public image and to make the programmes more effective by realigning the DTl's enterprise organisation institutional framework to enhance its assistance to small businesses. SEDA does not replace existing interventions by any stakeholders. Its aim is to ensure that new and existing publicsector programmes are coordinated. It also works towards the effective integration of financial and nonfinancial services for small businesses (DTI, 2005:16).

The objectives of SEDA are to design and implement development support programmes, to promote a service delivery network that increases the contribution of small enterprises to the South African economy, to promote economic growth, job creation and equity, and to generally strengthen the capacity of service providers to support small enterprises. It also assists small enterprises to compete successfully domestically and internationally. These objectives are aimed to build capacity and to make SMMEs more competitive, not only nationally but also internationally (SEDA, 2007:1).

\section{South African Micro-Finance Apex Fund (SAMAF)}

In 2004, the South African Micro-finance Apex Fund (SAMAF), commonly known as "Apex", has been established to address poverty alleviation and to provide sustained and affordable access to financial services for the poor. By 2004, SAMAF had pro-poor micro-finance institutions in all nine provinces. 
SAMAF will be an autonomous institution operationally independent of government. However, during the pilot phase it still operated as a Trading Account under the DTI (SAMAF, 2004:1).

Services offered by SAMAF include a Micro-credit Loan Fund that provides loans of up to R10 000 to households and micro-entrepreneurs who depend on micro-enterprises for their livelihood. This fund comprises of micro-credit for micro-enterprise development and the poverty alleviation fund for clients whose household incomes are less than R1 500.

The Institutional Capacity Building Fund provides funds to strengthen institutions and ensure its long-term sustainability. SAMAF's Savings Mobilisation serves to promote and encourage the creation of financial cooperatives and other savings establishments, such as stokvels and burial societies for the accumulation of locally owned and invested wealth (SAMAF, 2004:1).

\section{Refocused Approach by Khula}

After 2003 Khula had a number of successes which include increases in its approval rates, disbursements, business loans, credit indemnities, land reform empowerment facilities and Thuso mentorship assistance (Timm, 2006:1). Despite these successes, Khula also experienced some shortcomings and had to refocus their approach in servicing SMMEs. No data is available on the success rate of these loans and on whether the higher approval rate has decreased the repayment rate on these loans.

Khula Start, the entry-level programme of Khula that targeted the micro and survivalist sectors, was reviewed in 2001 as a result of serious deficiencies. These deficiencies include the operational procedures that were not always followed. This led to a lack of cohesion and the loss of power of group peer pressure to repay loans. Loans were also being approved for enterprises that were not always viable, because loan officers had failed to carry out appraisals prior to approval. Moreover, record keeping for management information systems was frequently deficient. (Motsa and Associates, 2004:29). They could also not produce records of their successes and failures so that the market could judge them. It is hoped that this situation will improve with these reforms.

Some of these programmes work for some small enterprises, but the very small and micro-enterprises still do not have a rightful share of these benefits (DTI, 1996b:3 and Berry et al., 2002:38). Khula was set up as a wholesaler in financing with the mandate to create and develop SMMEs by making loans and equity capital available particularly to previous disadvantaged SMMEs (Khula, 1998). It is difficult to carry out this mandate as Khula funds can only be accessed through banks and RFls. Khula has limited control over who receives the funds and admits that many small firms are still excluded from Khula funds. Banks are becoming less involved in Khula disbursements. Banks lent out 50 percent of this disbursement in the 2005/06 financial year, compared to 36 percent in 2006/07. However, loans through RFls increased from 14 percent in 2005/06 to 40 percent in 2006/07 (Mafu, 2007:1).

In most cases, small businesses that are capable of raising funds are assisted, while the plight of the micro-enterprises is still not addressed. The criteria set by the banks and RFIs are still too stringent for micro-enterprises. In this regard, Khula is planning to enable entrepreneurs to approach them directly for funds (Mafu, 2007:1). By approaching Khula directly, these programmes might be more accessible to SMMEs if the criteria become less stringent. Direct access will also counteract the decreasing participating role of commercial banks over the past years.

According to Solomon (2004:12), Khula programmes are supply-driven and do not cater for the needs of small businesses. In 2006 Khula announced the creation of new programmes such as the R100 million Khula/Enablis SME Acceleration Fund. The aim of this fund is to accelerate SMME growth in South Africa. This fund will provide "pre-venture capital" to SMME entrepreneurs. Enablis will also offer its entrepreneur members networking opportunities, skills development and training programmes as well as early-stage financing (Khula, 2006:1). Khula further bought an equity stake in Regent Factors. This equity 
stake made R100 million available for reverse factoring or supply chain finance. The reverse factoring intends to reduce the cash flow problems faced by SMMEs. Reverse factoring funding to SMMEs is not dependent on the borrower's ability to repay the loan, but on the creditworthiness of the supplier's customer. Reverse factoring will allow SMMEs to access much needed working capital by reducing the time gap between the delivery of goods and services and receipt of payment (Mokopanele, 2007:1).

The new developments and amendments over the past few years give an indication that the government is committed to the aims of the Small Business Development Policy of 1996. It also acknowledges that small business development agencies such as Ntsika and Khula had not delivered as expected (Motsa \& Associates, 2004:23). Government tried to address many of the shortcomings identified during the period 1996 and 2003 with these reforms. However, the effects of these reforms will only realise if all institutions are committed to the aims set by the Small Business Development Policy in 1996 and the aims set by the amendments in 2004. Moreover, it is important to monitor and evaluate the progress within the overall strategy and its different components and to publish this data on an annual basis. This will ensure that small businesses are supported and that it is not merely a reshuffling of institutions and programmes to conceal the failures of the past.

\section{IMPLICATIONS}

Many SMMEs still find it difficult to get support from the Small Business Support institutions because of many reasons. The fact that many SMMEs still do not get support, points to the shortcomings in the support programmes. Some of the shortcomings identified, include the fact that SMMEs are not aware of the programmes available to them. The institutions that provide these services should be made more visible. The second shortcoming is that not all programmes are easily accessible, because of the stringent criteria for assistance. These programmes are costly and commercial banks' participation in these programmes is still very small. The programmes do not cater for the needs of small and micro businesses and most benefits from these programmes benefit SMMEs in urban areas.

With the termination of Ntsika and the establishment of a larger institution, SEDA, the objectives of the larger institution were aimed to build capacity and to make SMMEs more competitive, not only nationally but also internationally. Although Khula's credit guarantees increased, commercial banks are becoming less involved in Khula disbursements than RFls. Khula's overall disbursements also increased, but the fact that business owners can only access Khula products at banks and RFls, excludes many SMMEs from benefiting from these programmes. Therefore, Khula is working on plans to enable entrepreneurs to approach them directly for funds.

Khula also introduced new products such as the Khula Enablis SME Acceleration Fund and reverse factoring or supply chain finance. This is not dependent on the borrower's ability to repay the loan, but on the creditworthiness of the supplier's customer. The introduction of the SAMAF will make funds affordable and accessible to micro-enterprises and SMMEs in rural areas, which can not access the government support programmes.

\section{CONCLUSIONS}

It is not always clear why the development and reforms of small business support institutions are needed or whether it is just a reshuffling of the institutions. Although government tries to address many of the shortcomings identified during the period 1996 to 2003, the public that can benefit from these changes are not informed properly. It is also important to monitor and evaluate the progress within the overall strategy and its different components, as well as to publish this data on an annual basis. This will lead to increased transparency in the small business support institutions. 


\section{REFERENCES}

Berry A, Von Blottnitz M, Cassim R, Kesper A, Rajaratnam B \& Van Seventer DE. 2002. The Economics of SMMES in South Africa. Johannesburg: Trade and Industrial Policy Strategies.

Bredenkamp M. 2002. An assessment of peoples bank business' service to SMMEs Sponsored by the Khula Indemnity Scheme. Unpublished Masters dissertation. Rand Afrikaans University.

Chalera CS. 2006. An impact analysis of South Africa's National Strategy for the development and promotion of SMMEs. Unpublished PhD thesis. Pretoria: University of Pretoria.

DTI. 1996a. Small business development policy. Department of Trade and Industry. Pretoria: Government Publishers.

DTI.1996b. National small business support strategy. Department of Trade and Industry. Pretoria: Government Publishers.

DTI. 2004. National Small Business Amendment Act. Department of Trade and Industry. Pretoria: Government Publishers.

DTI. 2005. Integrated Small-Enterprise-Development Strategy: Unlocking the potential of South African entrepreneurs. Department of Trade and Industry. Pretoria: Government Publishers.

DTI. 2005. Khula Financial products. Department of Trade and Industry. Pretoria. [Online] Available from: http://www.seda.org.za/content.asp?sublD=1 [Accessed: 25/02/2008].

Dorfling T. 2001. Enhancing Small, Medium and Micro-enterprise support provision: the case of Port Elizabeth, South Africa. Unpublished Masters dissertation. Johannesburg: University of Witwatersrand.

Eksteen W. 2001. Funding programmes run by government and parastatal agencies. Council for Scientific and Industrial Research. Pretoria: CSIR [Online] Available from: http://www. Nstf.org.za/set_funding/set_funding.asp/ [Accessed: 30/05/2006].

Global Insight, 2006. Rex. Socio Economic Database. Pretoria: Global Insight.

GIS. 2006. Employment strategy framework: part 2. Government Information Systems. Pretoria: Government Publishers [Online] Available from:

http://www. Polity.co.za/html/govdocs/misc/jobsframework1.html [Accessed: 24/11/2006].

Kesper A. 2002. Tracing trajectories of successful manufacturing SMMEs in South Africa. Unpublished $\mathrm{PhD}$ dissertation, University of Witwatersrand.

Khula. 1998. Annual Report, Pretoria: Khula Enterprise Finance Ltd.

Khula. 2002. Khula brings more South Africans into mainstream economy. Pretoria: Khula Enterprise Finance Ltd.

Khula. 2006. Khula and Enablis announce new R100-million acceleration fund for SMEs in South Africa. News release 19 October 2006 [Online] Available from: http://www.enablis.org/content/documents/FUND_LAUNCH_PRESS_RELEASE_(2).doc [Accessed: 02/11/2007].

Mafu T. 2007. Khula to lend to businesses shunned by banks. Business Report. 5 October 2007. 
Makina D \& Malobola M. 2005. Impact assessment of Micro-Finance Programmes: some lessons from Khula Enterprise Finance. Pretoria: University of South Africa.

Manning C. 1996. Market access for small and medium sized producers in South Africa: the case of the furniture industry. PhD dissertation, Brighton: University of Sussex.

Mokopanele T. 2007. South Africa: Cash flow made easy for SMEs. Business Day. 8 October 2007.

Motsa A \& Associates. 2004. SMME Finance Sector. Background Paper: A review of key documents on SMME Finance 1994-2004.

Nigrini M \& Schoombee A. 2002. Credit Guarantee Schemes as an instrument to promote access to finance for Small and Medium Enterprises: an analysis of Khula Enterprises Finance Ltd's individual credit Guarantee Scheme. Development Southern Africa, 19(5):735-750.

Orford J \& Wood E. 2005. Supporting small businesses in the Western Cape. Cape Town: Western Cape Provincial Government.

Qualmann R. 2000. Economic development and employment promotion in South Africa: analysis with special reference to SMME promotion and strategy options for the German Development Cooperation. Unpublished Report. Bonn: GTZ.

Rogerson CM. 2004. The Impact of the South African government's SMME programmes: A Ten Year Review (1994-2003). Development Southern Africa, 21(5):765-784.

SAMAF. 2004. South African Micro-finance Apex Fund Apex fund 2004. [Online] Available from: http://www.khula.org.zhttp://www.dti.gov.za/samaf/samaf.htma/South African Micro-finance Apex Fund (SAMAF) [Accessed: 02/11/2007].

SEDA. 2006. Press Release: Venture capital and equity funding. Pretoria: Small Enterprises Development Agency [Online] Available from: http://www.seda.org.za/content.asp?subld=176 [Accessed: 30/11/2006].

SEDA. 2007. Who we are. Pretoria: Small Enterprises Development Agency [Online] Available from: http://www.seda.org.za/content.asp?sublD=1 [Accessed: 03/11/2007].

Sithole X. 2005. Khula Annual Report. Pretoria: Khula [Online] Available from: http://www.seda.org.za/content.asp?sublD=1 [Accessed: 02/11/2007].

Solomon G. 2004. Entrepreneurship and the impact of entrepreneurial orientation training on SMMEs in the South African context: a longitudinal approach. Masters dissertation, Cape Town: University of Western Cape.

SSACI. 2002. Facing the future with courage. Swiss-South Africa Cooperation Initiative. Pretoria: SSACI. http://www.ssaci.org.za/news/news_0005.htm [Accessed: 24/11/2006].

Timm S. 2006. Loans up at Khula Business owner [Online] Available from: http://www.businessowner.co.za/Article [Accessed: 16/10/2007].

Wadula P. 2003. Ntsika restructures to change perceptions of small business sector. Business Day 13 March 2003.

World Bank. 2005. A better investment climate for everyone. World Development Report. 